\title{
Information for Authors
}

Authors are asked to forward their articles in both printed (single-sided with generous margins, double-spaced) and digitized form (the latter, if possible, in PC format, preferably using WORD-software) to the address: Department for South Asian, Tibetan and Buddhist Studies, University of Vienna, Spitalgasse 2, Hof $4 / 2$, A-1090 Vienna, Austria.

As regards the preparation of the contributions, the editors request attention to the following:

(1) One font size should be employed for the text as well as for the footnotes. Only the following font styles should be used: normal Roman (also for titles of primary literature) and italics (also for titles of books, journals, etc.; further see [3]). Letterspacing and underlining should not be used for emphasis; please resort to stylistic means instead. The text should contain a minimum of formatting and no end-of-line hyphenation. Paragraphs should be indicated with two hard returns, no tabulation. Character combinations should be completely avoided. For speceial characters please use Gandhari Unicode (http://depts.washington.edu/ebmp/software.html), if possible.

(2) The annotation is to be organized as consecutively numbered footnotes. The first of these $(*)$ should be reserved for acknowledgements or other preliminary remarks. Please refrain from arranging the footnote content in paragraphs.

(3a) Words and word forms used as such or cited, as well as citations from nonEuropean language original texts, should be set in italics. In prose citations, either vertical dandas or periods, commas and other conventional sentence markers should be employed, but in no case a combination of the two. Metrical texts should be marked respectively with single and double diagonal dandas at the end of half and full verses.

(3b) The following transcription systems are to be relied upon: for Sanskrit and related languages, the internationally accepted style (cf. the Poona Encyclopaedic Dictionary of Sanskrit on Historical Principles); for Tibetan, Viennese style; for Dravidian, the Burrow-Emeneau system; for Iranian, Hoffmann.

(4) Short citations and translations should appear within the running text and, except in the case of primary texts, be placed within double quotation marks. Longer citations and translations should appear as separate blocks, without quotation marks, set off from the rest of the text by left-indenting. Syntactically necessary additions to one's own translations should be placed in square brackets, explanations or other additions in round brackets.

(5a) Frequently mentioned primary and secondary literature should be referred to within the article itself in abbreviated form: in the case of primary texts via common sigla, in the case of secondary literature either by way of initial capital abbreviation (e.g. $M W$ or EIP I/1) or by way of author names, with or without date; page numbers should be indicated according to the models: EIP I/1/55, HIP II/235, $M W 555 b$ (s.v. nirdiś), Hacker 123 and Halbfass 1991: 32, n. 21. All sigla and ab- 
breviations should appear at the end of the article in a single alphabetically arranged abbreviations list which corresponds to the following examples:

EIP I/1

Granoff 1991

Granoff 1998

Hacker

Halbfass 1991

Halbfass 1995

HIP II

$\mathrm{MBh}$

MW

Tieken 2000

van Nooten 1994
Karl H. Potter, Encyclopedia of Indian Philosophies. Vol. I: Bibliography, Section 1. Delhi: Motilal Banarsidass, ${ }^{3} 1995$.

Phyllis Granoff, The Sacrifice of Manicūda: The Context of Narrative Action as a Guide to Interpretation. In: Kalyāna-mitta. Professor Hajime Nakamura Felicitation Volume, ed. V.N. Jha. [Bibliotheca Indo-Buddhica 86]. Delhi 1991, p. 225-239.

Id., Maitreya's Jewelled World: Some Remarks on Gems and Visions in Buddhist Texts. JIP 26 (1998) 347-371.

Paul Hacker, Philology and Confrontation. P.H. on Traditional and Modern Vedānta, ed. W. Halbfass. Albany: State University of New York Press, 1995.

Wilhelm Halbfass, The Therapeutic Paradigm and the Search for Identity in Indian Thought. In: Kalyāna-mitta (see Granoff 1991), p. 23-34.

Id., An Uncommon Orientalist: Paul Hacker's Passage to India. In: Hacker 1-23.

Erich Frauwallner, History of Indian Philosophy, tr. V.M. Bedekar. Vol. II: The Nature-Philosophical Schools and the Vaisesika System - The System of the Jaina - The Materialism. Delhi: Motilal Banarsidass, 1973.

Mahābhārata, ed. V.S. Sukthankar et al. (Poona 1933[1927]1959). Alternatively:

Mahābhārata: The Mahābhārata for the first time crit. ed. by V.S. Sukthankar, S.K. Belvalkar et al. 19 vols. Poona 1933(1927)-1959.

Monier Williams, A Dictionary English and Sanskrit. Delhi: Motilal Banarsidass, ${ }^{4} 1976$ (repr. 1999).

Herman Tieken, Aśoka and the Buddhist Samgha: A study of Aśoka's Schism Edict and Minor Rock Edict I. BSOAS $63(2000) 1-30$.

Barend A. van Nooten - Gary B. Holland, Rig Veda. A Metrically Restored Text with an Introduction and Notes. [HOS 50]. Cambridge, Mass.: Harvard University, 1994.

Common bibliographical, grammatical, etc. abbreviations need not be incorporated.

(5b) Alternatively, secondary literature may be fully documented (ef. [5a]) in a footnote upon initial mention, with subsequent citations therefrom referred back to the initial mention, according to the model: P. Hacker, Philology and Confrontation, ed. W. Halbfass. Albany 1995, p. 55f., n. 15 and P. Hacker, op. cit. (n. 5), p. 203. The titles of frequently employed primary sources should be written out in 
full and be followed by an abbreviated form in brackets upon initial mention; only the abbreviation should be used upon subsequent mention.

(6) Page numbers in cases other than those mentioned (ef. [5]) should be indicated with 'p.', note numbers with 'n.'; e.g. p. 75, n. 132.

(7) Numbers separated by way of a period or comma should be placed immediately adjacent to each other; e.g. MBh II 1,1, MBh 2,1,1 or MBh 2.1.1.

Please note that submitted contributions may not be offered at the same time to another journal.

Each author will receive without charge 25 offprints of their contribution; additional copies may be ordered at the author's cost when the final corrections are sent to the publisher. 